Review

\title{
ECONOMETRIC MODELS OF THE IMPACT OF MACROECONOMIC PROCESSES ON THE STOCK MARKET IN THE BALTIC COUNTRIES
}

\author{
Rimantas RUDZKIS ${ }^{\mathrm{a}}$, Roma VALKAVIČIENE ${ }^{\mathrm{b}}$ \\ anstitute of Informatics and Mathematics, Vilnius University, \\ Akademijos 4, LT-08663 Vilnius, Lithuania \\ ${ }^{\mathrm{b}}$ Department of Mathematical Statistics, Vilnius Gediminas Technical University, \\ Sauletekio al. 11, LT-10223 Vilnius, Lithuania
}

Received 13 November 2012; accepted 17 May 2014

\begin{abstract}
The article examines the dependencies of individual sectoral stock price indices of OMX Baltic security market on macroeconomic indicators, using econometric methods. Regression models are constructed using quarterly time series of 2000-2011 years while the methodology is backed with the findings of Lithuanian and foreign scientists from an extensive overview of specific literature. Regression equations, obtained in the paper, allows us to identify the key macroeconomic and global indicators that statistically significantly affect the Baltic securities market and to quantify their impact on the stock price indices of individual sectors in the Baltic countries. Econometric analysis of OMX Baltic security market proves the hypothesis that the set of macroeconomic regressors may vary considerably depending on the individual sector's price indices, especially in the case of small open economy with immature stock markets. The paper provides investors who are shaping their portfolios taking into account the macroeconomic forecasts with additional opportunities on the basis of sectoral stock price indices regression equations.
\end{abstract}

Keywords: sectoral indices of stock prices, macroeconomic indicators, OMX Baltic security market, econometric modelling, regression, forecast.

JEL Classification: C32, C51, C53, E44, G17.

Corresponding author Roma Valkavičienè

E-mail: roma.uzdanaviciute@gmail.com 


\section{Introduction}

The stock market is an essential part of the financial market that helps to redistribute financial resources among different economic subjects efficiently. In a modern economy, there are not only companies and various funds among direct and indirect stock market players but also an increasing number of individual players, therefore a considerable attention is paid to evolution of this market.

Aggregated stock prices indices help to represent the situation on the entire stock market and to track changes on the market. Stock prices are a subject of frequent fluctuations on the market, and both measurable quantitative (microeconomic, macroeconomic, exchange indicators of foreign countries, etc.) and ungrounded qualitative (social, psychological, political and others) factors determine their volatility. Various researches address this issue (Pyeman, Ahmad 2009; Ratneswary, Rasiah 2010; Filis 2010; Panetta 2002; Pilinkus 2010; Laskiené, Pekarskienè 2007; Humpe, Macmillan 2009; Wang, Lim 2010; Ibrahim 2011; Hosseini et al. 2011; Maysami et al. 2004; Buyuksalvarci 2010; and others).

If stock prices accurately reflect fundamental economic trends, then there should be a strong relationship between these price indices and economic activity indicators (Maysami et al. 2004). This hypothesis was addressed in a variety of scientific researches over more than three last decades. The researches were targeted at finding out whether:

- the stock market stimulates the economic growth of the country;

- the economic growth of the country invokes the stock market activity;

- there exists a causal interrelationship between them.

The empirical literature confirms that the behaviour of financial markets contain strong predictive power to country's economic development: rising stock prices indicate positive expectations of investors and potential economic growth while falling stock indices point to deteriorating performance of individual company or the entire economy and weakening prospects. Changes on the stock market affect not only the domestic trade, but are important factors in attracting foreign and institutional investors. Investors are interested in the stock market due to higher investment returns than in the money market. However, given the wide range of macroeconomic indicators, which describe the different regions, sectors, or companies investors consider it to be difficult to classify the individual sets of variables. Therefore, specific indices that reflect the region or the sector and their dynamics and magnitude are created. Wang and Lim (2010), Pyeman and Ahmad (2009), Maysami et al.(2004) emphasise that depending on sectoral peculiarities, the stock prices indices may be affected by different economic indicators. Moreover, their impact also depends on the country's fiscal and monetary policy (Chatziantoniou et al. 2013; Yartey 2010; Maysami, Sim 2001, 2002), maturity of the stock market, economic development level and other relevant parameters. Investigating the relationship between the country's macroeconomic factors and stock prices, by far most attention was paid to a well-developed securities market: USA (Shanken, Weinstein 1990), Great Britain (Morelli 2002), Japan (Hamao 1988; Mukherjee, Naka 1995), Italy (Panetta 2002), Spain (Martinez, Rubio 1989), France (Martinez 1999) and others. However, the economic role of stock markets in relatively small open dynamically developing countries is less clear. Specifically, how do less developed markets respond to changes in their funda- 
mental economic variables, compared with the well-developed and more efficient markets? The Baltic countries is that example of small open emerging economy in such cases: their economy has become much more related to the other economies, as international trade has expanded and financial integration with the rest of the world has deepened. Threrefore there is evidence that existing links, for example, stock prices of stock markets, may have become more important in the last few years.

This paper contributes to the literature by assessing the relationship between the macroeconomic indicators and stock price indices of OMX Baltic security market, which is relatively undeveloped. Key macroeconomic indicators of Lithuania, Latvia and Estonia which reflect the state of the countries' economy and its variation, were chosen. They are also accounted in all three countries, can be easily found in databases, their analogues are calculated in other countries and are also recommended by foreign and Lithuanian scientists. The analysis is also enriched with selected global indicators, which are relevant to the economic development of the Baltic countries. This makes the research topical - there are no published articles of this kind to authors' knowledge. Since the available quarterly data series are a little short, we have restricted ourselves to linear and log-linear models. When specifying these models, it was extremely important to determine the most explanatory factors - their influence on the created models statistically is defined by an appropriate significance level. In addition, the relationship between the stock market sector activity level and the macroeconomic factors may occur with a time lag. Therefore, it was also crucial to evaluate the selected macroeconomic indicators with the strongest effects on the examined indices over time. The paper concludes that the above mentioned assumption that the same economic indicators differently affect stock price indices of the individual economic sectors is confirmed by performed econometric analysis of OMX Baltic security market. The models make it possible to quantify the impact of the Baltic macroeconomic and selected global economic indicators on individual OMX Baltic securities market sectoral stock price indices. It provides additional opportunities for investors who are shaping their portfolio taking into account the macroeconomic forecasts.

The paper consists of 5 sections: introduction, econometric modelling of the stock prices peculiarities, primary specification of the models, analysis of results and conclusions.

The following section discusses the key aspects of stock prices econometric modelling: including the empirical econometric models of stock prices of various financial markets and assumptions used to construct those models. The section also includes an overview of specific literature on the hypotheses of the stock market and macroeconomic processes relationship.

In the second section, the series of economic indicators under consideration are concretised, and the methodology of the primary data analysis and specification of the economic model is described.

The third section deals with regression models of sectoral stock price indices of the Baltic countries. The statistically most significant factors for the development of an individual sector of the economy are distinguished based on the research results of an individual sector's stock index. The section also discusses economic interpretations of defined regression relationship.

In the final section conclusions about the model accuracy and prognosis probabilities are presented. 


\section{Peculiarities of stock price indices macroeconometric modelling}

The goal of applied analysis of the stock market indices is to choose a criterion that would allow to determine whether the investment into individual stock emission is attractive. This is a challenge, that requires a thorough analysis. The key findings from the related research survey are briefly presented in Table 1.

Table 1. Factors influencing stock prices of individual companies

\begin{tabular}{|c|c|c|}
\hline \multirow{7}{*}{ 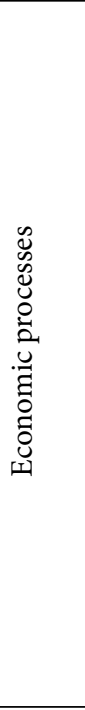 } & Reaction & Factors \\
\hline & $\begin{array}{l}\text { Impact of stock exchange } \\
\text { conditions on stock indices }\end{array}$ & Requirements to listing and membership, etc. \\
\hline & \multirow{3}{*}{$\begin{array}{l}\text { Macroeconomic effect on } \\
\text { stock indices }\end{array}$} & $\begin{array}{l}\text { Fiscal policy: domestic/foreign debt of the state, } \\
\text { unemployment level, inflation, revenues and expenditure } \\
\text { of the national budget, etc. }\end{array}$ \\
\hline & & $\begin{array}{l}\text { Monetary policy: government securities, interest of fixed } \\
\text { deposits and loans, monetary base, etc. }\end{array}$ \\
\hline & & $\begin{array}{l}\text { Other factors: GDP, direct foreign investments, } \\
\text { balance of international investments, etc. }\end{array}$ \\
\hline & $\begin{array}{l}\text { Microeconomic effect on stock } \\
\text { prices of enterprises }\end{array}$ & $\begin{array}{l}\text { Interest for stock, dividends, competitiveness of } \\
\text { an enterprise, assortment structure and realization } \\
\text { tendencies, profitability indicators, composition of } \\
\text { enterprise resources and liquidity (property structure), } \\
\text { structure of enterprise capital (structure of financial } \\
\text { sources), and others. }\end{array}$ \\
\hline & $\begin{array}{l}\text { Impact of other exchange } \\
\text { evolution on stock indices }\end{array}$ & Stock market indices of foreign countries, etc. \\
\hline 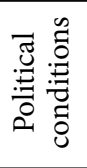 & $\begin{array}{l}\text { Effect of political decisions on } \\
\text { stock indices }\end{array}$ & Government change, elections, political discrepancy, etc. \\
\hline 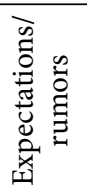 & $\begin{array}{l}\text { Impact of expectations and } \\
\text { rumors on prices and indices } \\
\text { of individual stocks }\end{array}$ & $\begin{array}{l}\text { Comments of competent persons in the mass media, } \\
\text { social disturbances, strikes, etc. }\end{array}$ \\
\hline
\end{tabular}

As shown in the Table 1, stock markets are affected by a number of factors. There are no possibilities for econometricians to find out their complex effect due to limited data series, therefore it is of special importance to select the primary quantitative factors.

\subsection{Methods and models}

The first theoretical investigations in this area were performed more than 30 years ago in the works of Fama and Schwert, Nelson also Jaffe and Mandelker, Ross (see Maysami et al. 2004). The researches conclude that capital markets can play a pivotal role in the economic financial sector of every country and can stimulate economic growth and prosperity, provided a basis to develop econometric models of various stock prices and to make deeper analysis of economic processes. Statistical stock indices were selected as characteristic features of 
the stock market state and its alteration tendencies, and macroeconomic indicators were treated as statistical indicators used for the assessment of the general economic condition of a country in a certain time period.

Poon and Taylor (1991) (UK), Hondroyiannis and Papapetrou (2001) (Greece), Ibrahim (2011) (Thailand), Nasseh and Strauss (2000) (France; Italy; Netherlands; Switzerland; UK; Germany), Maysami and Sim (2002) (Hong Kong and Singapore), Maysami and Koh (2000) (Singapore), Ratneswary and Rasiah (2010) (Malaysia), Hosseini et al. (2011) (China and India), Humpe and Macmillan (2009) (USA and Japan), Filis (2010) (Greece), Ratanapakorn and Sharma (2007) (USA), Buyuksalvarci (2010) (Turkey), Laskienè and Pekarskienė (2007) (Lithuania), Hsing ir Hsieh (2012) (Poland) explored long-run connections between macroeconomic indicators and stock price indices in the stock markets of the advanced and developing countries. In those works, there is a strong interrelationship between macroeconomic indicators and general indices reflecting the stock market state. In 2004, Maysami et al. analyzed relations between macroeconomic indicators and sectoral Singapore indices, while in 2009, Pyeman and Ahmad (2009) explored them in the case of Malaysia.

In the assessment of the impact of macroeconomic processes on the stock market, priorities of models in those works are most often not indicated, because the aims of research and data selection abilities are not comparable. Basing on the financial market research information in the works that came into our view, we can state that, to explain stock indices dependencies, the following statistical models and methods were used: Vector error correction model (VECM), Vector autoregression model (VAR), Granger causality test, Johansen and Juselius cointegration test, general correlation - regression analysis methods. In many aforementioned works, the authors recommended extending research models in the following aspects:

- to include new, not considered macroeconomic and sector economy indicators of a country (Pyeman, Ahmad 2009; Ratneswary, Rasiah 2010; Filis 2010; Panetta 2002; Maysami et al. 2004; Wang, Lim 2010);

- to estimate the impact of macroeconomic indicators with respect to varying stock indices, i.e. to distinguish coincident, lagging and precautionary behind indicators (Pilinkus 2010; Pyeman, Ahmad 2009);

- to choose different research periods, to classify them according to economics tendencies: stagnation, upswing, wars and others (Dubinskas, Stungurienė 2010; Laskiené, Pekarskienè 2007; Humpe, Macmillan 2009; Pyeman, Ahmad 2009; Ratneswary, Rasiah 2010; Nikkinen et al. 2012);

- to analyze stock market indices according to criteria such as monetary and fiscal policy, capitalization and geographical expansion, i.e. of individual states, state unions, regions, sectors, specialization types and other (Chatziantoniou et al. 2013; Humpe, Macmillan 2009; Wang, Lim 2010; Ibrahim 2011; Hosseini et al. 2011; Maysami et al. 2004; Buyuksalvarci 2010; Nikkinen et al. 2012; Wonga, Govindaraju 2012).

Thus, the review of econometric researches testifies that stock markets are strongly influenced by macroeconomic developments, however, this relation depends on peculiarities of the market. Models, formed for the specific countries, can be unfit for market prognosis of the other country, especially in the case of dynamically developing small open economies. 


\subsection{Hypotheses on dependencies of the stock market and macroeconomic processes}

Indicators that enable rendering the stock market state and its change tendencies are statistical stock indices aggregating stock prices of separate firms. Stock prices are constantly changing in the market, many factors determine instability: both measurable quantitative factors (microeconomic, macroeconomic, exchange indicators of foreign countries, etc.) and ungrounded qualitative factors (social, psychological, political and others). The assessment of the influence of the country's macroeconomic processes on stock indices changes using the intuitive finance theory hypotheses on dependencies of the above economic processes is described in various articles:

\section{A negative connection between the interest rate and stock price \\ Causes:}

1. Interest rates can affect the level of enterprise profit which, in turn, affects the price that the investors are ready to pay for a stock, based on the expectations of high dividend payment in the future. The majority of companies finance the acquisition of their capital equipment and inventory via loans. The fall in the interest rate decreases the borrowing expenses, thus promoting enterprises to expand. This fact stimulates the positive effect on future expectations of enterprise profit.

2. A large number of stocks most frequently is acquired by means of borrowed money, therefore an increase in the interest rate raises the price of securities bargains. Investors expect a higher rate of return even before investing, so that the investment would pay back. High investment prices decrease the demand for stocks as well as their price thereby (Pearce, Roley 1983).

Therefore, the interest rate is one of the most important factors that influence stock prices. Ratanapakorn and Sharma (2007) have explored the dependence of the USA stock prices on the interest rate in the period of 1975-1999 and obtained a strong negative relationship as well.

\section{A negative relationship between inflation and stock price}

Causes: an increasing inflation level may compel to take more drastic measures of the monetary policy, which, in turn, increases the nominal non-risky rate of interest and thereby raises the discount rate. The effect of a high discount rate will not necessarily be neutralised by increasing cash flows, appearing due to a higher inflation, because cash flows, as usual, do not grow at the same rate as inflation.

The results of many investigations have shown a adverse relationship between inflation and stock price: Fama (1981), Geske and Roll (1983), Chen et al. (1986), Pearce and Roley (1983), Mukherjee and Naka (1995), Humpe and Macmillan (2009), Hsing and Hsieh (2012). However, the contradictory results have been obtained in financial markets of India and China (Hosseini et al. 2011).

\section{A relation between exchange rates, exports and stock price}

Chandran and Rasiah (2013) have found evidence that export has impact on the firm's performance but this relation is not single-valued and may be different in individual markets. Causes: currency depreciation allows an increase in demand for export and augmentation of monetary flows to a country (under the assumption that the demand for export is relatively 
flexible). The growth of demand for export will raise the level of the stock market by showing that the payback of the stock market positively correlates with varying currency exchange rates (Mukherjee, Naka 1995; Ratanapakorn, Sharma 2007). However, if currency consolidation is expected, then the market becomes more attractive for investment. The impact of changes in currency exchange rates on economics for the most part depends on the level of international trade and trade balance. A negative relation was found in Turkey's (Buyuksalvarci 2010) and Poland's (Hsing, Hsieh 2012) financial markets.

\section{A positive relationship between industrial production volume and stock price Causes:}

1. Tainer suggests that the industrial production index is pro-cyclical, i.e. it rises during economic expansion and falls during recession (see Maysami et al. 2004). The growth of industrial production is a token of economic uprising, therefore, the index is used as an indicator of economics.

2. Geske and Roll (1983), Ratanapakorn and Sharma (2007), Humpe and Macmillan (2009) have made a hypothesis of the positive relationship, indicating that with the growth of industrial production volume, flows of enterprise money are also increasing respectively, which promotes investors to acquire stocks, their demand is increasing and stock indices are growing as well.

Conclusions of Chen et al. (1986) state that, based on the USA stock portfolio, the growth of industrial production is a significant factor that explains the uprise of stock prices. Fama (1981) has established previously that the speed of industrial growth has a strong link with securities payback.

\section{Relationship between money supply and stock price}

Causes: The growth rates of the money supply (M2) affects the overall economy and, therefore, the stock price growth is expected. M2 money growth increases the liquidity of the securities, thus increasing the stock price due to the increasing demand for them. Hsing and Hsieh (2012), Ariff et al. (2012), Bilson et al. (2001), Ratanapakorn and Sharma (2007), Humpe and Macmillan (2009), Hosseini et al. (2011) have found a strong correlation between those two variables empirically. However, according to Mukherjee and Naka (1995), the impact of the money supply on securities prices is ambiguous. Increase in the money supply leads to inflation and may increase the discount rate, as well as a consequent reduction of stock prices (Fama 1981), thus showing a negative correlation.

\section{A positive relationship between GDP and stock price}

Causes: GDP is a robust factor that predetermines changes in the financial market (Glen 2002; Bilson et al. 2001; Ritter 2005; Hsing, Hsieh 2012; Miller, Ratti 2009). With the growth of the gross domestic product, the activity of the stock market also increases, because the residents get higher income and the economic - financial results of issuers become better. This fact increases the stock attractiveness of enterprises both of local and foreign investors, and potential opportunities for investment become better, too. With an increase of demand for stocks, their holders are interested in selling them for a higher price. Thus the stock price is increasing and, in turn, indices of stocks are growing as well. With the help of VAR methodology, Gjerde and Sattem (1999) have considered financial markets of several coun- 
tries (Canada, Australia, Sweden and Norway) and have drawn a conclusion that economic activities have a positive impact on the securities market, but they attracted attention to the fact that the stock market reacts to GDP changes with delay.

\section{A negative relationship between gold price and stock prices}

Causes: in the global market gold is considered as an alternative investment product dependent on estimated returns (Buyuksalvarci 2010). Its prices tend to considerably bounce when the global economy faces serious economic, political and geopolitical risks. Also, it is commonly used for protection against unreasonable fear or panic, because unlike other types of assets, gold does not provide any additional income. Meanwhile, the stocks promise dividends, bonds have coupons, houses provide lease revenue, etc.

\section{A negative relationship between unemployment and stock prices}

Causes: Unemployment is regarded as one of the most important and the most common macro-economic problems of the country. Unemployment level rises when the economy is in recession, and it decreases rapidly when economy is growing. With an increase of unemployment, enterprise investments are decreasing as well as the real income of employed, therefore the opportunity for saving and investing also decreases, - the available savings are meant for consumption (Rafael, Tvaronavičienè 2005).

A negative connection between oil price and stock price

Jones and Kaul (1996) and Sadorsky (1999) have explored the relation between oil and stock prices. All of them have drawn a conclusion that changes in oil prices is and important factor that decide a change in return of the securities market.

Causes: Oil prices can influence the general stock market both directly and indirectly. The direct negative impact can be explained by the fact that certain shifts of the increasing oil prices arouse some uncertainty in financial markets, which, in turn, can invoke a decrease in stock prices. The indirect negative effect of higher oil prices can be considered as a factor that determines a lower production level and a higher inflation level. The negative relation between oil prices and stock return is also documented by Gjerde and Sattem (1999) in the stock market of Norway, by Ciner (2001), and O’Neill et al. (2008), Sadorsky (1999), Buyuksalvarci (2010) in Turkey, by Hosseini et al. (2011) in India (positive relationship was found in China stock market).

The results of the above mentioned researches of conjugate relations in different financial markets of the world are very helpful when specifying more complex vector regression models of the Baltic countries' stock markets. It is likely the interrelationship of stock prices and macroeconomic indicators in this region is similar to that in the developed markets.

\section{Econometric model selection and primary specification of sectoral stock price indices}

On the basis of the stock price econometric models, created by researchers in Lithuania and abroad, their assumptions and economic hypotheses, a statistical model of the dependence of the Baltic countries sectoral stock price indices on the Baltic macroeconomic indicators and global variables is constructed. 


\subsection{Statistical data}

As far as modern aspirations of the three Baltic countries for economic and political integration are similar, their stock exchanges have formed a common OMX Baltic securities market in order to diminish differences between securities of Lithuania, Estonia and Latvia, and to facilitate the trade by securities. Consequently, there is evidence that stock prices of the new emerging stock market have become more important in the last few years.

The research objectives of this work are sectoral indices of the OMX Baltic stock prices in the securities market (10 indices). Prices of enterprices' stocks are included automatically and number of enterprices in them can vary. A descriptive statistics of quarterly changes (percent) in the period of the years 2000-2011 is shown in Table 2.

Also, Table 2 shows the volume of the sectors in 2011, which gives a measure of how developed are countries' sectors in the Baltic market. As shown, in 2011 the Baltic securities market amounted to 77 companies. Most of the companies were in Industrials, Consumer Discretionary, and Consumer Staples sectors. These three sectors accounted for $63.6 \%$ of the total market companies. The Baltic stock market enterprises in sectors in 2011 are listed in Appendix of this article.

Table 2. Descriptive statistics of sectoral stock price indices change in a quarter (percent) from 2000 to 2011 and the size of the Baltic stock market sector by the number of enterprises in 2011

\begin{tabular}{|c|c|c|c|c|c|c|c|c|c|}
\hline \multirow{2}{*}{$\begin{array}{l}\text { Name of } \\
\text { the sectoral } \\
\text { index (GICS } \\
\text { classification }^{1} \text { ) }\end{array}$} & \multicolumn{4}{|c|}{$\begin{array}{l}\text { The number of enterprises in the } \\
\text { market }\end{array}$} & \multirow{2}{*}{$\begin{array}{l}\text { Marking } \\
\text { of Index } \\
\text { change }\end{array}$} & \multirow{2}{*}{ Mean } & \multirow{2}{*}{$\begin{array}{l}\text { Std } \\
\text { Dev }\end{array}$} & \multirow{2}{*}{ Min } & \multirow{2}{*}{ Max } \\
\hline & $\begin{array}{c}\text { Baltic } \\
\text { countries }\end{array}$ & Lithuania & Latvia & Estonia & & & & & \\
\hline Energy & 3 & 1 & 2 & 0 & $Y_{1}$ & 2.79 & 13.23 & -33.17 & 31.23 \\
\hline Materials & 5 & 1 & 4 & 0 & $Y_{2}$ & 2.33 & 18.72 & -41.35 & 51.07 \\
\hline Industrials & 19 & 6 & 9 & 4 & $Y_{3}$ & 2.54 & 17.51 & -42.24 & 48.52 \\
\hline $\begin{array}{l}\text { Consumer } \\
\text { Discretionary } \\
\end{array}$ & 16 & 7 & 4 & 5 & $Y_{4}$ & 4.28 & 17.33 & -50.79 & 45.37 \\
\hline Consumer Staples & 14 & 8 & 5 & 1 & $Y_{5}$ & 2.40 & 12.67 & -42.43 & 29.00 \\
\hline Health Care & 5 & 0 & 5 & 0 & $Y_{6}$ & 7.46 & 18.79 & -57.97 & 60.97 \\
\hline Financials & 6 & 3 & 1 & 2 & $Y_{7}$ & 4.38 & 18.66 & -65.24 & 36.57 \\
\hline $\begin{array}{l}\text { Information } \\
\text { Technology }\end{array}$ & 1 & 0 & 1 & 0 & $Y_{8}$ & 3.36 & 37.15 & -41.41 & 203.26 \\
\hline $\begin{array}{l}\text { Telecommunication } \\
\text { Services }\end{array}$ & 1 & 1 & 0 & 0 & $Y_{9}$ & -0.16 & 10.54 & -27.96 & 17.09 \\
\hline Utilities & 7 & 5 & 1 & 1 & $Y_{10}$ & 4.48 & 17.04 & -32.17 & 50.19 \\
\hline Total & 77 & 32 & 32 & 13 & & & & & \\
\hline
\end{tabular}

Source: OMX Baltic security market data (2011), calculations by authors.

Based on the experience in this area (see the review of references in section 2), 23 variables were selected in order to form regression models, the quarterly data for their calculation were taken from Eurostat and financial terminal of the Web bases. To avoid seasonal effect, under

\footnotetext{
1 Global Industry Classification Standard.
} 
the present possibilities, seasonally adjusted series were used (seasonally adjusted observations of those indicators are submitted by the official statistics). Percentage of quarterly changes of several common macroeconomic indicators of the Baltic countries (Lithuania, Latvia and Estonia) as well as of some indicators that illustrate global markets have been analyzed as independent variables. Descriptive statistics of the relevant time series is presented in Table 3.

Table 3. Descriptive statistics of quarterly changes (percent) in the economic indicators that define factors from 2000 to 2011

\begin{tabular}{|c|c|c|c|c|c|}
\hline Description of economic indicator & $\begin{array}{l}\text { Indicator } \\
\text { change }\end{array}$ & Mean & StdDev & Min & Max \\
\hline Government loans (EUR mio) & $X_{1}$ & 3.70 & 13.68 & -13.66 & 59.44 \\
\hline Government consolidated gross debt (EUR mio) & $X_{2}$ & 3.62 & 6.47 & -5.30 & 30.03 \\
\hline Foreign official reserves (including gold) ${ }^{2}$ & $X_{3}$ & 3.09 & 8.39 & -35.74 & 24.43 \\
\hline Gross domestic product $^{2}$ & $X_{4}$ & 2.87 & 9.61 & -20.10 & 18.45 \\
\hline The volume of exports ${ }^{3}$ & $X_{5}$ & 3.48 & 8.88 & -24.02 & 22.85 \\
\hline The volume of imports ${ }^{2}$ & $X_{6}$ & 3.66 & 11.07 & -31.28 & 22.14 \\
\hline Net national disposable income ${ }^{2}$ & $X_{7}$ & 2.92 & 10.41 & -21.15 & 18.90 \\
\hline Gross national disposable income $^{2}$ & $X_{8}$ & 3.22 & 11.62 & -24.31 & 21.31 \\
\hline Gross savings and GDP ratio ${ }^{2}$ & $X_{9}$ & 3.60 & 3.53 & -4.04 & 11.66 \\
\hline Gross savings $^{2}$ & $X_{10}$ & 6.29 & 23.52 & -34.34 & 48.72 \\
\hline Expenditure on fixed capital formation ${ }^{4}$ & $X_{11}$ & 2.89 & 11.09 & -36.35 & 31.34 \\
\hline Current transfers, receivable & $X_{12}$ & 3.99 & 10.96 & -18.40 & 36.73 \\
\hline Money supply ${ }^{1}$ & $X_{13}$ & 3.76 & 9.95 & -13.58 & 50.29 \\
\hline The inter-bank lending rate of interest ( 3 month) & $X_{14}$ & 0.25 & 24.17 & -67.52 & 90.45 \\
\hline Consumer price index & $X_{15}$ & 1.00 & 1.10 & -0.89 & 4.35 \\
\hline Construction volume index & $X_{16}$ & 10.16 & 38.56 & -52.91 & 76.07 \\
\hline $\begin{array}{l}\text { The unemployment rate } \% \\
\text { (15-64 years old citizens) }\end{array}$ & $X_{17}$ & 0.66 & 13.13 & -15.78 & 47.49 \\
\hline The index of the active number of employees & $X_{18}$ & -0.01 & 1.92 & -4.84 & 3.86 \\
\hline $\begin{array}{l}\text { The index of the number of employees } \\
\text { in the trade sector }\end{array}$ & $X_{19}$ & 3.55 & 0.73 & -6.28 & 1.02 \\
\hline $\begin{array}{l}\text { The index of the number of employees } \\
\text { in the construction sector }\end{array}$ & $X_{20}$ & 5.88 & 1.97 & -14.87 & 0.82 \\
\hline Oil price (Brent type, USD per barrel) & $X_{21}$ & 4.67 & 17.42 & -58.91 & 47.42 \\
\hline Gold price (USD/ounce) & $X_{22}$ & 3.85 & 5.58 & -6.58 & 14.22 \\
\hline USD/EUR exchange rate & $X_{23}$ & 0.77 & 4.50 & -12.43 & 7.37 \\
\hline
\end{tabular}

Source: Eurostat database data (2011), calculations by authors.

By the way, some factors (other market indices of Poland, Hungary and etc.) have been examined which are not shown in Table 3 . Since they were not statistically significant they are not mentioned in this work.

\footnotetext{
2 Calculated at the end of the period, EUR mio.

3 Calculated at current prices, EUR mio.

4 Seasonally adjusted time series.
} 


\subsection{Formation of a linear regression model}

Due to the sheer number of factors and shortness of the existing time series, statistical model development involved three stages. Initially, an exploratory analysis was made, which aims to select the most informative factors and their lags. At this stage, the $Y(t)$ contacts with each $X(t)$ factor separately are investigated, and the significance of the linear regression model is evaluated:

$$
Y_{k}(t)=\alpha+\sum_{i=0}^{4} \beta_{i j} X_{j}(t-i)+\varepsilon(t), \quad t=\{1,2, \ldots, 48\}, \quad j=\{1,2, \ldots, 23\}, \quad k=\{1,2, \ldots, 10\} .
$$

In the next stage, a general model is composed for each group index change:

$$
Y_{k}(t)=\alpha+\sum_{i=0}^{4} \sum_{j=1}^{23} \beta_{i j} X_{j}(t-i)+\varepsilon(t), \quad t=\{1,2, \ldots, 48\}, \quad k=\{1,2, \ldots, 10\} .
$$

When identifying it by the least squares method, we evaluate only these coefficients at those factors which were recognised as statistically significant in the first stage of modelling ( $\mathrm{p}$-value does not exceed 0.05), while the rest coefficients are equalised to zero. Afterwards, the significance of regressors in the general model was defined and insignificant factors were successively eliminated one-by-one from the model.

After testing the above mentioned random errors by statistical hypotheses verification, assumptions of homoscedasticity were not rejected, maybe due to the shortness of the series (Table 4).

Table 4. Homoscedasticity of the stock price sectoral indice models: p-value of Breusch - Pagan test

\begin{tabular}{cccccccccc}
\hline$Y_{1}(t)$ & $Y_{2}(t)$ & $Y_{3}(t)$ & $Y_{4}(t)$ & $Y_{5}(t)$ & $Y_{6}(t)$ & $Y_{7}(t)$ & $Y_{8}(t)$ & $Y_{9}(t)$ & $Y_{10}(t)$ \\
\hline$(0.050)$ & $(0.054)$ & $(0.052)$ & $(0.058)$ & $(0.055)$ & $(0.051)$ & $(0.054)$ & $(0.060)$ & $(0.061)$ & $(0.053)$ \\
\hline
\end{tabular}

However, after leaving only statistically significant factors, large number of parameters remained in equations in terms of having in index the length of the series (48). In order to increase the stability of models, forward and backward procedures were applied in the third stage. With their help we strove to select the most informative factors and to reduce the number of coefficients estimated in model up to 7 .

\section{Investigation of results of sectoral stock price indices modelling}

Regression equations of sectoral indices dependencies allows us to identify the key macroeconomic and global indicators, that statistically significantly affect fluctuations of the securities market and to quantify their impact on the stock price indices corresponding to different sectors of the economy. The conventional model specification tests do not indicate specification problems. The comparison of the regression model accuracy with the autoregressive investigation results, obtained in the Uzdanavičiūte, Rudzkis (2011) paper, testifies that the values of model statistics $\mathrm{R}^{2}$ in the latter work did not achieve 0.5 , while the values of statistics presented in Table 5 amounted to $0.77-0.96$. 
794 R. Rudzkis, R. Valkavičiene. Econometric models of the impact of macroeconomic processes...

Table 5. Accuracy of the stock price sectoral indice models: the values of statistics R2

\begin{tabular}{cccccccccc}
\hline$Y_{1}(t)$ & $Y_{2}(t)$ & $Y_{3}(t)$ & $Y_{4}(t)$ & $Y_{5}(t)$ & $Y_{6}(t)$ & $Y_{7}(t)$ & $Y_{8}(t)$ & $Y_{9}(t)$ & $Y_{10}(t)$ \\
\hline 0.8019 & 0.8695 & 0.9663 & 0.9396 & 0.8842 & 0.8695 & 0.8370 & 0.8596 & 0.8517 & 0.7687 \\
\hline
\end{tabular}

The studies have corroborated a large impact of macroeconomic factors on the stock price sectoral indices of all the Baltic countries. The equations of $Y(t)$ regression models, identified using the quarterly data of 2000-2011, $-X(t)$ independent economic indicators, their estimated coefficients and significance levels ( $\mathrm{p}$-value values are presented in brackets) are shown in Table 6.

Table 6. Investigation results of regression models of sectoral stock price indices

\begin{tabular}{|c|c|c|c|c|c|c|c|}
\hline$Y(t)$ & Intercept & $X_{1}(t)$ & $X_{2}(t)$ & $X_{14}(t)$ & $X_{22}(t)$ & $X_{13}(t-1)$ & $X_{20}(t-1)$ \\
\hline$Y_{1}(t)$ & $\begin{array}{c}23.11 \\
(0.0008)\end{array}$ & $\begin{array}{c}1.78 \\
(0.0007) \\
\end{array}$ & $\begin{array}{c}-4.39 \\
(0.0003)\end{array}$ & $\begin{array}{c}-0.24 \\
(0.0252)\end{array}$ & $\begin{array}{c}-1.76 \\
(0.0004)\end{array}$ & $\begin{array}{c}0.86 \\
(0.0067)\end{array}$ & $\begin{array}{c}-0.99 \\
(0.0152)\end{array}$ \\
\hline \multirow{3}{*}{$Y_{2}(t)$} & Intercept & $X_{23}(t)$ & $X_{1}(t)$ & $X_{2}(t)$ & $X_{4}(t-1)$ & $X_{15}(t)$ & $X_{13}(t-1)$ \\
\hline & 0.45 & 2.94 & 3.02 & -5.91 & 8.68 & -13.48 & 1.55 \\
\hline & $(0.0358)$ & $(0.0284)$ & $(0.0200)$ & $(0.0106)$ & $(0.0477)$ & $(0.0588)$ & $(0.0576)$ \\
\hline \multirow{3}{*}{$Y_{3}(t)$} & Intercept & $X_{23}(t-1)$ & $X_{2}(t)$ & $X_{5}(t)$ & $X_{6}(t)$ & $X_{15}(t)$ & $X_{22}(t)$ \\
\hline & 56.36 & 2.82 & -4.59 & 5.47 & -5.76 & -17.73 & -2.86 \\
\hline & $(0.0110)$ & $(0.0255)$ & $(0.0355)$ & $(0.0211)$ & $(0.0083)$ & $(0.0128)$ & $(0.0235)$ \\
\hline \multirow{3}{*}{$Y_{4}(t)$} & $X_{1}(t)$ & $X_{2}(t)$ & $X_{14}(t)$ & $X_{17}(t-1)$ & $X_{4}(t)$ & $X_{15}(t)$ & $X_{22}(t)$ \\
\hline & 3.02 & -3.91 & -0.44 & -1.43 & 14.08 & -17.59 & -2.28 \\
\hline & $(0.0014)$ & $(0.0084)$ & $(0.0331)$ & $(0.0273)$ & $(0.0147)$ & $(0.0018)$ & $(0.0033)$ \\
\hline \multirow{3}{*}{$Y_{5}(t)$} & Intercept & $X_{2}(t)$ & $X_{17}(t-1)$ & $X_{15}(t)$ & $X_{22}(t-1)$ & & \\
\hline & 0.10 & -2.87 & -0.62 & -7.07 & -0.95 & & \\
\hline & $(0.0482)$ & $(0.0390)$ & $(0.0915)$ & $(0.0260)$ & $(0.0524)$ & & \\
\hline \multirow{3}{*}{$Y_{6}(t)$} & Intercept & $X_{23}(t)$ & $X_{2}(t)$ & $X_{19}(t-1)$ & $X_{15}(t-1)$ & $X_{22}(t)$ & $X_{13}(t-1)$ \\
\hline & 0.43 & 2.36 & -3.89 & 3.99 & -17.51 & -2.65 & 1.23 \\
\hline & $(0.0449)$ & $(0.0589)$ & $(0.0570)$ & $(0.0182)$ & $(0.0127)$ & $(0.0189)$ & $(0.0137)$ \\
\hline \multirow{3}{*}{$Y_{7}(t)$} & Intercept & $X_{23}(t-1)$ & $X_{2}(t)$ & $X_{14}(t)$ & $X_{3}(t)$ & $X_{22}(t)$ & $X_{21}(t)$ \\
\hline & 0.22 & -0.92 & -2.82 & -0.44 & 0.99 & -2.18 & 0.77 \\
\hline & $(0.0117)$ & $(0.0540)$ & $(0.0398)$ & $(0.0015)$ & $(0.0261)$ & $(0.0011)$ & $(0.0055)$ \\
\hline \multirow{3}{*}{$Y_{8}(t)$} & Intercept & $X_{17}(t)$ & $X_{4}(t)$ & $X_{5}(t)$ & $X_{20}(t-1)$ & $X_{16}(t)$ & $X_{11}(t)$ \\
\hline & -0.24 & -1.31 & 30.76 & 3.16 & 0.90 & 1.27 & -2.33 \\
\hline & $(0.0507)$ & $(0.0260)$ & $(0.0036)$ & $(0.0479)$ & $(0.0322)$ & $(0.0063)$ & $(0.0309)$ \\
\hline \multirow{3}{*}{$Y_{9}(t)$} & $X_{1}(t-1)$ & $X_{14}(t-1)$ & $X_{4}(t)$ & $X_{12}(t)$ & $X_{15}(t)$ & $X_{13}(t-1)$ & \\
\hline & -0.30 & -0.29 & 7.09 & 0.03 & -6.37 & 0.48 & \\
\hline & $(0.0324)$ & $(0.0094)$ & $(0.0394)$ & $(0.0196)$ & $(0.0370)$ & $(0.0411)$ & \\
\hline \multirow{3}{*}{$Y_{10}(t)$} & Intercept & $X_{23}(t)$ & $X_{17}(t)$ & $X_{3}(t)$ & $X_{15}(t-1)$ & $X_{22}(t-1)$ & $X_{21}(t-1)$ \\
\hline & 0.08 & 1.21 & 0.78 & 1.24 & 9.30 & -1.02 & -0.45 \\
\hline & $(0.0581)$ & $(0.0117)$ & $(0.0502)$ & $(0.0116)$ & $(0.0252)$ & $(0.0524)$ & $(0.0395)$ \\
\hline
\end{tabular}


Each model was intended to describe the basic dependencies so that the model would be relatively stable (of low sensitivity to the available data sample removal). It is noteworthy that in 7 sectors out of 10 there are less than 7 companies, therefore the indices of these sectors are strongly influenced by the activities of individual companies, and as a result, the accuracy of respective models is not very high. After receiving additional data, it is needed to perform a more detailed study of these sectors.

As shown, the developed models accurately described the index behaviour of the particular Industrials and Consumer Discretionary sectors, which are the most numerous (see Table 2 and Table 1A in Appendix). As was expected, the operation results of individual companies, which were not reflected in the models, have a lower impact on the average prices of sector companies, if the sectors are more numerous. The largest errors have been obtained when modelling the index of Utilities (state-owned enterprises are predominant here), however, even in this case the model accuracy is quite high. In order to further increase the accuracy of modelling and to expand prediction abilities, it is necessary to incorporate into models the data of individual economic activities of a country in addition to macroeconomic variables. The authors are planning to devote another study to this topic.

The most important indicators to the Energy sector index are the government debt and price of gold. The impact of the first factor is negative and evident, since the major investment in the Baltic countries is directed specifically to the field of energy, and the growing public debt put a limit on these investments. Bonds comprise the largest stock of the public debt, while loans make up only a small portion of it and are usually taken for specific projects. The data shows indirectly that they on average have a positive effect on the value of the quoted companies, because the model coefficient of the government loans variable both of this and other sector indices is positive. The negative coefficient at the price of gold only confirms the known rule that the prices of gold and securities generally move in the opposite directions.

The public debt ratio is the most significant factor in the Materials sector index of the model, followed by government loans, - signs of the coefficients are the same as those discussed in the Energy model. Calculations show that another important factor is the USD/EUR exchange rate - the reasons for this relationship are likely to be part of exports to the dollar area markets.

The most significant factors of the Industrials sector price index are the volume of imports and the inflation rate. Both the corresponding coefficients are negative which has an economic sense: both import growth ahead of exports, and a rapid increase in the consumer price often indicates the problems of production companies.

The most significant factors of the Consumer Discretionary sector price index are the government loans, the inflation rate, the price of gold, and the national debt. The signs of the coefficients are the same as that in the discussed models. This index rather heavily depends on GDP and the unemployment rate.

The regression model of the Consumer Staples sector price index has only three statistically significant factors if we apply the critical significance level of 0.05 . The model was expanded by the unemployment rate that was statistically significant only with the critical level 0.1 . The main impact on this sector index is made by inflation and public debt ratios and the coefficients of both signs are correct - negative. 
Variations of money amounts and the number of staff in domestic trade (which partly reflects domestic consumption) have a positive influence on the Health Care sector price index, while changes in inflation and the price of gold have a negative effect.

As expected, the inter-bank lending rate of interest as well as the factors reflecting global markets such as the price of gold and oil, are of particular important for the price index in the model of Financial sector (its impact is negative). The correlation between the latter index and the price index of the Financial sector is positive.

Information Technology and Telecommunications Services sectors of the OMX Baltic countries' securities market have only one company each, therefore the models of stock price indices of these sectors are of little interest and will not be commented here separately.

The most important variables in the price index model of the Utilities sector are changes in the official international reserves and in the U.S. dollar exchange rate as well as the inflation index.

Generalizing the investigation results, we see that the impact of the factors considered on price indices of individual sectors is quite different: the same indicators in one model is very important and in another it is statistically insignificant, besides, one index it affects positively while in another it stipulates negative changes. The results provide their impact depends on size of companies in each sector which is strongly influenced by the activities of individual companies. After receiving additional data, it is needed to perform a more detailed study of these sectors.

In the variation of stock indices in Telecommunications and Utilities sectors we can observe a greater influence of warning indicators in a quarter. The influence of global indicators (USD/EUR exchange rate, the price of gold and oil) is most observed in the Utilities, Financial, Health Care, and Industrials sectors while in the rest of them macroeconomic indicators of the Baltic countries are of particular importance.

The results of the research illustrate that it is worthwhile to go beyond the analysis of the general OMX Baltic market price index and to model the aforementioned sectoral indices, in case we have reliable macroeconomic forecasts and application of sector models enables us to predict the OMX Baltic security market development more accurately.

\section{Conclusions}

Macroeconomic indicators of the Baltic countries and the leading global stock exchange indicators (dollar/euro exchange rate, gold and oil prices) have a significant impact on the OMX Baltic securities market. In addition, the impact of the same factors on individual sector indices is quite different. It is therefore reasonable and appropriate to model not only general, but also sectoral stock market price indices.

The linear regression models have a fairly high level of precision and provide additional opportunities for investors who are shaping their portfolio taking into account the macroeconomic forecasts.

Due to the shortness of the available time series, the influence of several factors was not reflected in the models. In view of the new data accumulated, the models should be expanded 
and updated. One of the ways of improving them is to consider not only macroeconomic indicators as factors that affect sectoral indices, but also to include statistical data of the respective economic activities. Moreover, in the case of the longer time series, we should apply a generalised least squares method.

\section{References}

Ariff, M.; Chung, T.; Shamsher, M. 2012. Money supply, interest rate, liquidity and share prices: a test of their linkage, Global Finance Journal 23(3): 202-220. http://dx.doi.org/10.1016/j.gfj.2012.10.005

Bilson, C. M.; Brailsford, T. J.; Hooper, V. J. 2001. Selecting macroeconomic variables as explanatory factors of emerging stock market returns, Pacific-Basin Finance Journal 9(4): 401-426. http://dx.doi.org/10.1016/S0927-538X(01)00020-8

Buyuksalvarci, A. 2010. The effects of macroeconomics variables on stock returns: evidence from Turkey, European Journal of Social Sciences 14(3/4): 13.

Chandran, V. G. R.; Rasiah, R. 2013. Firm size, technological capability, exports and economic performance: the case of electronics industry in Malaysia, Journal of Business Economics and Management 14(4): 741-757. http://dx.doi.org/10.3846/16111699.2012.668860

Chatziantoniou, I.; Duffy, D.; Filis, G. 2013. Stock market response to monetary and fiscal policy shocks: multi-country evidence, Economic Modelling 30: 754-769. http://dx.doi.org/10.1016/j.econmod.2012.10.005

Chen, N.; Roll, R.; Ross, S. 1986. Economic forces and the stock market, The Journal of Business 59(3): 383-403. http://dx.doi.org/10.1086/296344

Ciner, C. 2001. Energy shocks and financial markets: nonlinear linkages, Studies in Nonlinear Dynamics and Econometrics 5(3): 203-212. http://dx.doi.org/10.2202/1558-3708.1079

Dubinskas, P.; Stungurienè, S. 2010. Alterations in the financial markets of the Baltic countries and Russia in the period of economic downturn, Technological and Economic Development of Economy 16(3): 502-515. http://dx.doi.org/10.3846/tede.2010.31

Eurostat database data. 2011. [online], [cited 30 october 2014]. European Commission. Available from Internet: http://epp.eurostat.ec.europa.eu/portal/page/portal/statistics/search_database

Fama, E. 1981. Stock return, real activity, inflation and money, The American Economic Review 65: 269-282.

Filis, G. 2010. Macro economy, stock market and oil prices: do meaningful relationships exist among their cyclical fluctuations?, Energy Economics 32(4): 877-886. http://dx.doi.org/10.1016/j.eneco.2010.03.010

Geske, R.; Roll, R. 1983. The fiscal and monetary linkage between stock returns and inflation, The Journal of Finance 38(1): 1-33. http://dx.doi.org/10.1111/j.1540-6261.1983.tb03623.x

Gjerde, O.; Sattem, F. 1999. Causal relations among stock returns and macroeconomic variables in a small, open economy, Journal of International Financial Markets, Institutions and Money 9(1): 61-74. http://dx.doi.org/10.1016/S1042-4431(98)00036-5

Glen, J. 2002. Devaluations and emerging stock market returns, Emerging Markets Review 3(4): 409-428. http://dx.doi.org/10.1016/S1566-0141(02)00044-4

Hamao, Y. 1988. An empirical examination of the Arbitrage Pricing Theory: using Japanese data, Japan and the World Economy 1(1): 45-61. http://dx.doi.org/10.1016/0922-1425(88)90005-9

Hondroyiannis, G.; Papapetrou, E. 2001. Macroeconomic influence on the stock market, Journal of Economics and Finance 25(1): 33-49. http://dx.doi.org/10.1007/BF02759685

Hosseini, S. M.; Ahmad, Z.; Lai, Y. W. 2011. The role of macroeconomic variables on stock market index in China and India, International Journal of Economics and Finance 3(6): 12.

http://dx.doi.org/10.5539/ijef.v3n6p233 
Hsing, Y.; Hsieh, W. 2012. Impacts of macroeconomic variables on the stock market index in Poland: new evidence, Journal of Business Economics and Management 13(2): 334-343. http://dx.doi.org/10.3846/16111699.2011.620133

Humpe, A.; Macmillan, P. 2009. Can macroeconomic variables explain long-term stock market movements? A comparison of the US and Japan, Applied Financial Economics 19(2): 111-119. http://dx.doi.org/10.1080/09603100701748956

Ibrahim, M. H. 2011. Stock market development and macroeconomic performance in Thailand, Inzinerine Ekonomika - Engineering Economics 22(3): 230-240. http://dx.doi.org/10.5755/j01.ee.22.3.513

Jones, C. M.; Kaul, G. 1996. Oil and the stock markets, The Journal of Finance 51(2): 463-491. http://dx.doi.org/10.1111/j.1540-6261.1996.tb02691.x

Laskienè, D.; Pekarskiene, I. 2007. The relation between the stock price of Lithuanian enterprise and macroeconomic factors, Economics and Management 12: 791-797.

Maysami, R. C.; Howe, L. C.; Hamzah, M. A. 2004. Relationship between macroeconomic variables and stock market indices: cointegration evidence from stock exchange of Singapore's all-S sector indices, Journal Pengurusan 24: 47-77.

Maysami, R. C.; Koh, T. S. 2000. A vector error correction model of the Singapore stock market, International Review of Economics and Finance 9(1): 79-96. http://dx.doi.org/10.1016/S1059-0560(99)00042-8

Maysami, R. C.; Sim, H. H. 2002. Macroeconomic variables and their relationship with stock returns: error correction model evidence from Hong Kong and Singapore, The Asian Economic Review: Journal of the Indian Institute of Economics 44(1): 69-85.

Maysami, R. C.; Sim, H. H. 2001. Macroeconomic forces and stock returns: a general-to-specific ECM analysis of the Japanese and South Korean markets, International Quarterly Journal of Finance 1(1): 83-99.

Martinez, I. 1999. Fundamental and macroeconomic information for the security prices valuation: the French case, Managerial Finance 25(12): 17-30. http://dx.doi.org/10.1108/03074359910766316

Martinez, M. A.; Rubio, G. 1989. Arbitrage pricing with macroeconomic variables: an empirical investigation using Spanish data, Working paper, Universidad del Pais Vasco.

Miller, J. I.; Ratti, R. A. 2009. Crude oil and stock markets: stability, instability, and bubbles, Energy Economics 31(4): 559-568. http://dx.doi.org/10.1016/j.eneco.2009.01.009

Morelli, D. 2002. The relationship between conditional stock market volatility and conditional macroeconomic volatility: empirical evidence based on UK data, International Review of Financial Analysis 11(1): 101-110. http://dx.doi.org/10.1016/S1057-5219(01)00066-7

Mukherjee, T. K.; Naka, A. 1995. Dynamic relations between macroeconomic variables and the Japanese stock market: an application of a vector error correction model, The Journal of Financial Research 18(2): 223-237.

Nasseh, A.; Strauss, J. 2000. Stock prices and domestic and international macroeconomic activity: a cointegration approach, The Quarterly Review of Economics and Finance 40(2): 229-245. http://dx.doi.org/10.1016/S1062-9769(99)00054-X

Nikkinen, J.; Piljak, V.; Aijo, J. 2012. Baltic stock markets and the financial crisis of 2008-2009, Research in International Business and Finance 26(3): 398-409. http://dx.doi.org/10.1016/j.ribaf.2012.03.003

OMX Baltic security market data. 2011. [online], [cited 30 October 2014]. Nasdaq. Available from Internet: http://www.nasdaqomxbaltic.com/market/?lang=lt

O'Neill, T. J.; Penm, J.; Terrell, R. D. 2008. The role of higher oil prices: a case of major developed countries, Research in Finance 24: 287-299. http://dx.doi.org/10.1016/S0196-3821(07)00211-0

Panetta, F. 2002. The stability of the relation between the stock market and macroeconomic forces, Economic Notes, Review of Banking, Finance and Monetary economics 31(3): 417-450. http://dx.doi.org/10.1111/1468-0300.00093 
Pearce, D. K.; Roley, V. V. 1983. The reaction of stock prices to unanticipated changes in money: a note, The Journal of Finance 38(4): 1323-1333. http://dx.doi.org/10.1111/j.1540-6261.1983.tb02303.x

Pilinkus, D. 2010. Macroeconomic indicators and their impact on stock market performance in the short and long run: the case of the Baltic states, Technological and Economic Development of Economy 16(2): 291-304. http://dx.doi.org/10.3846/tede.2010.19

Pyeman, J.; Ahmad, I. 2009. Dynamic relationship between sector-specific indices and macroeconomic fundamentals, Malaysian Accounting Review 8(1): 81-100.

Poon, S.; Taylor, S. J. 1991. Macroeconomic factors and the UK stock market, Journal of Business Finance \& Accounting 18(5): 619-636. http://dx.doi.org/10.1111/j.1468-5957.1991.tb00229.x

Rafael, Ž.; Tvaronavičiene, M. 2005. Quantitative analysis of influential factors in the Lithuanian enterprises stock and stock indexes, Business: Theory and Practise VI(3): 159-170.

Ratanapakorn, O.; Sharma, S. C. 2007. Dynamic analysis between the US stock returns and the macroeconomic variables, Applied Financial Economics 17(5): 369-377. http://dx.doi.org/10.1080/09603100600638944

Ratneswary, R.; Rasiah, V. 2010. Macroeconomic activity and the Malaysian stock market: empirical evidence of dynamic relations, The International Journal of Business and Finance Research 4(2): 59-69.

Ritter, J. R. 2005. Economic growth and equity returns, Pacific-Basin Finance Journal 13(5): 489-503. http://dx.doi.org/10.1016/j.pacfin.2005.07.001

Sadorsky, P. 1999. Oil price shocks and stock market activity, Energy Economics 21(5): 449-469. http://dx.doi.org/10.1016/S0140-9883(99)00020-1

Shanken, J.; Weinstein, M. I. 1990. Macroeconomic variables and asset pricing: estimation and tests, Working paper, University of Rochester.

Uzdanavičiūte, R.; Rudzkis, R. 2011. The Baltic countries sectoral share price indexes VAR model, in Proc. of the Lithuanian Mathematical Society: VU Institute of Mathematics and Informatics 52: 332-337.

Wang, G.; Lim, C. 2010. Effects of macroeconomic factors on share prices, Journal of International Finance and Economics 10(2): 113-123.

Wong, C. Y.; Govindaraju, V. G. R. C. 2012. Technology stocks and economic performance of government-linked companies: the case of Malaysia, Technological and Economic Development of Economy 18(2): 248-261. http://dx.doi.org/10.3846/20294913.2012.688313

Yartey, C. A. 2010. The institutional and macroeconomic determinants of stock market development in emerging economies, Applied Financial Economics 20(21): 1615-1625. http://dx.doi.org/10.1080/09603107.2010.522519 


\section{APPENDIX}

Table 1A. The list of enterprises of the Baltic stock market sectors in 2011

\begin{tabular}{ll}
\hline \multicolumn{1}{c}{ Sector name } & \multicolumn{1}{c}{ The list of enterprises belonging to the sector } \\
\hline Energy & Klaipedos nafta, Latvijas kugnieciba, Ventspils nafta \\
\hline \multirow{2}{*}{ Materials } & Olaines kudra, Liepajas metalurgs, Saldus mezrupnieciba, \\
& Talsu mezrupnieciba, Grigiskes \\
\hline & Dvarcioniu keramika, Valmieras stikla skiedra, Jarvevana, \\
& Latvijas tilti, Merko Ehitus, Nordecon, Panevezio statybos trestas, \\
& Harju Elekter, Rigas elektromasinbuves rupnica, Daugavpils \\
& Lokomotivju remonta rupnica, Rigas kugu buvetava, \\
Industrials & Tosmares kugubuvetava, Ditton pievadkezu rupnica, City Service, \\
& Lietuvos juru laivininkyste, Limarko laivininkystes Kompani, \\
& Tallink Grupp, Liepajas autobusu parks, Nordeka \\
\hline \multirow{3}{*}{ Consumer Discretionary } & Rigas autoelektroaparatu rupnica, VEF Radiotehnika RRR, \\
& Kurzemes atslega 1, Klaipedos baldai, Vilniaus baldai, Viisnurk, \\
& Snaige, Baltika, Rigas juvelierizstradajumu rupnica, Utenos trikotazas, \\
& Linas, Olympic Entertainment Group, Ekspress Grupp, \\
& Tallinna Kaubamaja, Apranga, Silvano Fashion Group \\
\hline \multirow{2}{*}{ Consumer Staples } & Gubernija, Latvijas balzams, Vilniaus degtine, Agrowill Group, \\
& Grobina, Linas Agro Group, Brivais vilnis, Kurzemes CMAS, \\
& Premia Foods, Pieno zvaigzdes, Rokiskio suris, Siguldas CMAS, \\
& Vilkyskiu pienine, Zemaitijos pienas \\
\hline Health Care & Grindeks, Latvijas Zoovetapgade, Latvijas Juras medicinas centrs, \\
\hline Financials & Rigas farmaceitiska fabrika, Olainfarm \\
\hline Information Technology & Arco Vara, Invalda, Siauliu bankas, Trigon Property Development, \\
\hline Telecommunication & Ukio bankas, VEF \\
\hline \multirow{2}{*}{ Utilities } & SAF Tehnika \\
\hline & TEO LT \\
\hline & LESTO, Lietuvos energija, Litgrid, Latvijas Gaze, Lietuvos dujos, \\
& Tallinna Vesi, Kauno energija \\
\hline
\end{tabular}

Rimantas RUDZKIS. Doctor Habilitatus in Mathematics, Senior Researcher at the Vilnius University Institute of Mathematics and Informatics, and Professor at the Department of Mathematical Statistics of Vilnius Gediminas Technical University. Author of more than 60 scientific articles. Research interests: large deviations of random values and processes, adaptive statistical analysis of spectral density and distribution density, cluster analysis, applications of statistics, econometric modelling of Lithuanian macroeconomic processes.

Roma VALKAVIČIENĖ. PhD student at the Department of Mathematical Statistics of Vilnius Gediminas Technical University. Received BSc degree in Applied Mathematics in 2005 from Kaunas Technology University, MSc degree in Applied Statistics in 2007, respectively from Vilnius Gediminas Technical University. Research interests: econometric modelling, statistical analysis system software, business intelligence analysis. 